Article

\title{
Nanoparticulate palladium catalyst stabilized by supported on feather keratin for Suzuki coupling reaction
}

\author{
MA Hengchang*, BAO Zhikang, HAN Guobin, YANG Ningning, XU Yufei, YANG Zengming, CAO Wei, \\ MA Yuan
}

Key Laboratory of Polymer Materials of Gansu Province, Key Laboratory of Eco-Environment-Related Polymer Materials Ministry of Education, College of Chemistry and Chemical Engineering, Northwest Normal University, Lanzhou 730070, Gansu, China

\section{A R T I C L E I N F O}

Article history:

Received 30 September 2012

Accepted 23 October 2012

Published 20 March 2013

\section{Keywords:}

Suzuki reaction

Nanoparticle

Feather keratin

Hydrophobic effect

Water

\begin{abstract}
A B S T R A C T
Palladium nanoparticles supported in a feather keratin matrix were efficient catalyst for the coupling reactions of aryl bromides with arylboronic acid in aqueous medium under mild reaction conditions. The biopolymer-based catalyst demonstrated excellent activity for substrates with a wide range of functional groups. The product biaryls were precipitated from the reaction mixture with good to excellent yields and purities. The catalyst was recovered from the reaction solution easily by simple filtration, and can be reused at least seven times.
\end{abstract}

(C) 2013, Dalian Institute of Chemical Physics, Chinese Academy of Sciences. Published by Elsevier B.V. All rights reserved.

\section{Introduction}

Metal nanoparticles have a high surface-to-volume ratio and consequently a large fraction of the metal atoms is exposed to reactant molecules, which makes them promising catalysts in chemical synthesis [1,2]. However, the direct application of noble metal nanoparticles in catalysis is often difficult due to their very small size and high tendency toward agglomeration by van der Waals forces. Polymer matrixes can serve as the support for these materials for keeping the nanoparticles from aggregation, provide the desired interface between the nanoparticles and the reaction media, and facilitate the synthesis and reuse of the catalysts.

It has been extensively demonstrated that palladium nanoparticles entrapped in a polymer matrix are good heterogeneous catalysts for $\mathrm{C}-\mathrm{C}$ bond formation reactions. In particular, encouraging results were achieved in the cross-coupling of arylboronic acids with aryl halides. The common used polymer matrixs were polystyrene [3,4], poly(amidoamine)-dendrimer [5,6], cyclodextrin [7], poly( $N$-vinyl-2-pyrrolidone) (PVP) [8-10], polystyrene-co-poly[2-methacrylic acid] 3-bis-(carboxymethylamino)-2-hydroxypropyl ester [11], poly( $N$-isopropylacrylamide), the water-compatible biopolymer chitosan [12,13], ethylenediamine-functionalized cellulose [14], polystyrene-poly(ethylene oxide) copolymer, Amberlite IRA 900 [15], polyaniline nanofibers [16], aminomethylated TentaGel resin [17], merrifield resin [18], phosphanated copolymer [19], and the copolymer of styrene with glycidyl methacrylate (GMA) and iminodiacetic acid (IDA) [20]. In many cases, the polymer-supported catalyst has extremely small and uniform Pd clusters, which were $1 \mathrm{~nm}$ [19], $1.4 \pm 0.4 \mathrm{~nm}$ [6], 2.0 $\mathrm{nm}$ [5], $2.3 \pm 0.3 \mathrm{~nm}[21], 3.8 \mathrm{~nm}$ [22], and $6 \mathrm{~nm}$. [20].

The Suzuki reaction is perhaps the most powerful and versatile method for the formation of new biaryls [15,23-29]. This

\footnotetext{
* Corresponding author. Tel/Fax: +86-931-7975257; E-mail: mahczju@hotmail.com

This work was supported by the National Natural Science Foundation of China (21202133).

DOI: 10.1016/S1872-2067(11)60472-5 | http://www.sciencedirect.com/science/journal/18722067 | Chin. J. Catal., Vol. 34, No. 3, March 2013
} 
is due to the ease of the synthesis and handling and the wide functional group tolerance of aryl boronic acids as compared with Grignard reagents, and also the reactants have relatively low toxicity as compared with the aryl tin reagents. Recent publications have already focused on developing new catalysts for the Suzuki reaction using supported nanoparticle palladium [30-34], but given the importance of the reaction, there is a need to investigate more suitable stabilizer materials and to address the questions of product isolation and catalyst recyclability. Our research in the field of biopolymer-based materials prompted us to investigate the use of feather protein as a green support material for palladium nanoparticles [35]. Feather keratin is a natural polymer consisting of numerous amino acids units. Due to their biodegradability, biocompatibility, and ready availability, keratins are attracting growing interest as environmentally friendly substitutes for classical organic and inorganic supports [36-41].

\section{Experimental}

\subsection{Preparation of feather keratin-Pd nanoparticles}

The Pd nanoparticles were prepared by the process previously described [34]. A $10 \mathrm{ml}$ aqueous solution of $\mathrm{PdCl}_{2}$ (10 $\mathrm{mg}$ ) and $1 \mathrm{~g}$ of feather keratin $[42,43]$ were stirred at room temperature $\left(25-30{ }^{\circ} \mathrm{C}\right)$ until the color of the solution became transparent. After filtrating, the bright yellow solid was charged into $10 \mathrm{ml}$ deionized water and an excess amount of sodium ascorbate (500 $\mathrm{mg}$ ) was added. The mixture was vigorously stirred for $24 \mathrm{~h}$ until the color of the solid changed to dark brown, and then the filtrated solid was washed with deionized water and ketone several times. The powder was dried in vacuo at $30^{\circ} \mathrm{C}$ overnight (Pd content: $8.8 \%$ ).

\subsection{Characterization}

Transmission electron microscopy (TEM) measurement was conducted using a Philips T20ST electron microscope at an acceleration voltage of $200 \mathrm{kV}$. NMR Data for Products 1c-27c were as follow.

Biphenyl (1c) [24]. ${ }^{1} \mathrm{H}$ NMR (400 MHz, $\left.\mathrm{CDCl}_{3}\right), \delta 7.48(\mathrm{~m}$, $4 \mathrm{H}), 7.32(\mathrm{~m}, 4 \mathrm{H}) . \mathrm{mp} 70-72^{\circ} \mathrm{C}$.

Biphenyl-4-ol (2c) [58]. ${ }^{1} \mathrm{H}$ NMR (400 MHz, $\left.\mathrm{CDCl}_{3}\right), \delta 7.54$ (m, 2H), $7.48(\mathrm{~m}, 2 \mathrm{H}), 7.41(\mathrm{~m}, 2 \mathrm{H}), 7.29(\mathrm{~m}, 1 \mathrm{H}), 6.91(\mathrm{~m}, 2 \mathrm{H})$, $4.82(\mathrm{~m}, 1 \mathrm{H}) \cdot \mathrm{mp} 164-165^{\circ} \mathrm{C}$.

4-methylbiphenyl (3c) [19]. ${ }^{1} \mathrm{H}$ NMR (400 $\mathrm{MHz}^{\mathrm{CDCl}} 3$ ), $\delta$ $7.58(\mathrm{~m}, 3 \mathrm{H}), 7.50(\mathrm{~m}, 2 \mathrm{H}), 7.44(\mathrm{~m}, 3 \mathrm{H}), 7.26(\mathrm{~m}, 1 \mathrm{H}), 3.84(\mathrm{~m}$, $3 \mathrm{H}) . \mathrm{mp} 60-62^{\circ} \mathrm{C}$.

4-nitrobiphenyl (4c) [19]. ${ }^{1} \mathrm{H}$ NMR (400 $\mathrm{MHz}^{\left.-\mathrm{CDCl}_{3}\right), \delta 8.25}$ (m, 2H), 7.74 (m, 2H), 7.48 (m, 2H), 7.32 (m, 3H). mp 118-120 ${ }^{\circ} \mathrm{C}$.

biphenyl-4-carbaldehyde (5c) [56]. ${ }^{1} \mathrm{H}$ NMR (400 MHz, $\left.\mathrm{CDCl}_{3}\right), \delta 9.87(\mathrm{~m}, 1 \mathrm{H}), 7.87(\mathrm{~m}, 2 \mathrm{H}), 7.67(\mathrm{~m}, 2 \mathrm{H}), 7.48(\mathrm{~m}, 2 \mathrm{H})$, $7.32(\mathrm{~m}, 2 \mathrm{H}) . \mathrm{mp} 62-65^{\circ} \mathrm{C}$.

biphenyl-4-amine (6c)[58]. ${ }^{1} \mathrm{H}$ NMR (400 $\left.\mathrm{MHz}, \mathrm{CDCl}_{3}\right), \delta$ $7.53(\mathrm{~m}, 2 \mathrm{H}), 7.40(\mathrm{~m}, 4 \mathrm{H}), 7.26(\mathrm{~m}, 1 \mathrm{H}), 6.74(\mathrm{~m}, 2 \mathrm{H}), 3.67(\mathrm{~m}$, 2H); m.p. $53-55^{\circ} \mathrm{C}$. 4-methoxybiphenyl (7c) [19]. ${ }^{1} \mathrm{H}$ NMR (400 $\left.\mathrm{MHz} \mathrm{CDCl}_{3}\right), \delta$ $7.54(\mathrm{~m}, 4 \mathrm{H}), 7.41(\mathrm{~m}, 2 \mathrm{H}), 7.27(\mathrm{~m}, 1 \mathrm{H}), 6.97(\mathrm{~m}, 2 \mathrm{H}), 3.85(\mathrm{~m}$, $3 \mathrm{H})$. $\mathrm{mp} 88-90^{\circ} \mathrm{C}$.

4-ethoxybipheny (8c) [17]. ${ }^{1} \mathrm{H}$ NMR (400 $\mathrm{MHz}^{\left.-\mathrm{CDCl}_{3}\right), \delta}$ $7.53(\mathrm{~m}, 4 \mathrm{H}), 7.41(\mathrm{~m}, 2 \mathrm{H}), 7.26(\mathrm{~m}, 2 \mathrm{H}), 6.96(\mathrm{~m}, 1 \mathrm{H}), 4.08(\mathrm{~m}$, $2 \mathrm{H}), 1.44(\mathrm{~m}, 3 \mathrm{H})$.

2,4-dimethoxybiphenyl (9c) [56]. ${ }^{1} \mathrm{H}$ NMR (400 MHz, $\left.\mathrm{CDCl}_{3}\right)$, $\delta 7.48(\mathrm{~m}, 2 \mathrm{H}), 7.38(\mathrm{~m}, 4 \mathrm{H}), 6.51(\mathrm{~m}, 2 \mathrm{H}), 3.84(\mathrm{~m}, 6 \mathrm{H})$.

2-phenylpyridine (10c) [56]. ${ }^{1} \mathrm{H}$ NMR (400 $\left.\mathrm{MHz}^{\mathrm{CDCl}} 3\right): \delta$ $8.70(\mathrm{~m}, 1 \mathrm{H}), 7.98(\mathrm{~m}, 2 \mathrm{H}), 7.75(\mathrm{~m}, 2 \mathrm{H}), 7.48(\mathrm{~m}, 3 \mathrm{H}), 7.43(\mathrm{~m}$, $1 \mathrm{H})$.

2-phenylthiophene (11c) [57]. ${ }^{1} \mathrm{H}$ NMR (400 MHz, $\left.\mathrm{CDCl}_{3}\right), \delta$ $7.61(\mathrm{~m}, 2 \mathrm{H}), 7.37(\mathrm{~m}, 2 \mathrm{H}), 7.28(\mathrm{~m}, 3 \mathrm{H}), 7.08(\mathrm{~m}, 1 \mathrm{H})$.

4'-methoxybiphenyl-4-ol (12c). ${ }^{1} \mathrm{H}$ NMR (400 MHz, $\left.\mathrm{CDCl}_{3}\right), \delta$ $7.45(\mathrm{~m}, 4 \mathrm{H}), 6.96(\mathrm{~m}, 2 \mathrm{H}), 6.89(\mathrm{~m}, 2 \mathrm{H}), 4.73(\mathrm{~m}, 1 \mathrm{H}), 3.84(\mathrm{~m}$, $3 \mathrm{H})$; ${ }^{13} \mathrm{C}$ NMR $(100 \mathrm{MHz}, \mathrm{CDCl} 3): \delta 158.6,138.6,133.4,127.7$, 124.8, 114.1, 102.6, 55.3. $\mathrm{mp} 180-183{ }^{\circ} \mathrm{C}$.

4-methoxy-4'-methylbiphenyl (13c) [56]. ${ }^{1} \mathrm{H}$ NMR (400 $\left.\mathrm{MHz}, \mathrm{CDCl}_{3}\right), \delta 7.48(\mathrm{~m}, 4 \mathrm{H}), 7.24(\mathrm{~m}, 2 \mathrm{H}), 6.96(\mathrm{~m}, 2 \mathrm{H}), 3.85(\mathrm{~m}$, $3 \mathrm{H}), 2.38(\mathrm{~m}, 3 \mathrm{H})$.

4-methoxy-4'-nitrobiphenyl (14c) [34]. ${ }^{1} \mathrm{H}$ NMR (400 MHz, $\left.\mathrm{CDCl}_{3}\right), \delta 7.93(\mathrm{~m}, 4 \mathrm{H}), 7.48(\mathrm{~m}, 2 \mathrm{H}), 6.97(\mathrm{~m}, 2 \mathrm{H}), 3.85(\mathrm{~m}, 3 \mathrm{H})$; ${ }^{13} \mathrm{C}$ NMR $\left(100 \mathrm{MHz}, \mathrm{CDCl}_{3}\right): \delta 158.6,133.4,127.7,114.1,55.3$. mp $110-113^{\circ} \mathrm{C}$.

4'-methoxybiphenyl-4-carbaldehyde (15c). ${ }^{1} \mathrm{H}$ NMR $(400$ $\left.\mathrm{MHz} \mathrm{CDCl}_{3}\right), \delta 10.04(\mathrm{~m}, 1 \mathrm{H}), 7.92(\mathrm{~m}, 2 \mathrm{H}), 7.73(\mathrm{~m}, 2 \mathrm{H}), 7.60$ $(\mathrm{m}, 2 \mathrm{H}), 7.03(\mathrm{~m}, 2 \mathrm{H}), 3.87(\mathrm{~m}, 3 \mathrm{H}) ;{ }^{13} \mathrm{C} \mathrm{NMR}\left(100 \mathrm{MHz}, \mathrm{CDCl}_{3}\right)$ : $\delta 191.9,160.1,146.8,134.6,132.0,130.2,128.5,127.0,114.2$, 55.4. $\mathrm{mp} 105-108^{\circ} \mathrm{C}$.

4'-methoxybiphenyl-4-amine (16c). ${ }^{1} \mathrm{H}$ NMR (400 MHz, $\left.\mathrm{CDCl}_{3}\right), \delta 7.46(\mathrm{~m}, 2 \mathrm{H}), 7.36(\mathrm{~m}, 2 \mathrm{H}), 6.96(\mathrm{~m}, 2 \mathrm{H}), 6.74(\mathrm{~m}, 2 \mathrm{H})$, $3.84(\mathrm{~m}, 3 \mathrm{H}), 3.66(\mathrm{~m}, 2 \mathrm{H}) . \mathrm{mp} 153-155^{\circ} \mathrm{C}$.

4,4'-dimethoxybiphenyl (17c) [34]. ${ }^{1} \mathrm{H}$ NMR (400 MHz, $\left.\mathrm{CDCl}_{3}\right), \delta 7.48(\mathrm{~m}, 4 \mathrm{H}), 6.96(\mathrm{~m}, 4 \mathrm{H}), 3.84(\mathrm{~m}, 6 \mathrm{H}) ;{ }^{13} \mathrm{C} \mathrm{NMR}$ $\left(100 \mathrm{MHz}, \mathrm{CDCl}_{3}\right): \delta 127.8,115.6,114.1,55.3 . \mathrm{mp} 168-170^{\circ} \mathrm{C}$.

4-ethoxy-4'-methoxybiphenyl (18c). ${ }^{1} \mathrm{H}$ NMR $(400 \mathrm{MHz}$, $\left.\mathrm{CDCl}_{3}\right), \delta 7.47(\mathrm{~m}, 4 \mathrm{H}), 6.96(\mathrm{~m}, 4 \mathrm{H}), 4.07(\mathrm{~m}, 3 \mathrm{H}), 3.85(\mathrm{~m}, 3 \mathrm{H})$, $1.43(\mathrm{~m}, 3 \mathrm{H})$.

2,4,4'-trimethoxybiphenyl (19c). ${ }^{1} \mathrm{H}$ NMR (400 $\left.\mathrm{MHz}^{\mathrm{CDCl}} 3\right)$, $\delta 7.42(\mathrm{~m}, 2 \mathrm{H}), 7.21(\mathrm{~m}, 1 \mathrm{H}), 6.94(\mathrm{~m}, 2 \mathrm{H}), 6.55(\mathrm{~m}, 2 \mathrm{H}), 3.83$ $(\mathrm{m}, 9 \mathrm{H})$.

2-(4-methoxyphenyl)pyridine (20c). ${ }^{1} \mathrm{H}$ NMR (400 MHz, $\left.\mathrm{CDCl}_{3}\right), \delta 8.66(\mathrm{~m}, 1 \mathrm{H}), 7.95(\mathrm{~m}, 2 \mathrm{H}), 7.70(\mathrm{~m}, 2 \mathrm{H}), 7.18(\mathrm{~m}, 1 \mathrm{H})$, $7.00(\mathrm{~m}, 2 \mathrm{H}), 3.85(\mathrm{~m}, 3 \mathrm{H})$.

2-(4-methoxyphenyl)thiophene (21c). ${ }^{1} \mathrm{H}$ NMR $(400 \mathrm{MHz}$, $\left.\mathrm{CDCl}_{3}\right), \delta 7.37(\mathrm{~m}, 2 \mathrm{H}), 7.20(\mathrm{~m}, 1 \mathrm{H}), 6.99(\mathrm{~m}, 2 \mathrm{H}), 6.83(\mathrm{~m}, 2 \mathrm{H})$, $3.73(\mathrm{~m}, 3 \mathrm{H})$.

4'-chlorobiphenyl-4-carbaldehyde (22c) [54]. ${ }^{1} \mathrm{H}$ NMR (400 $\mathrm{MHz} \mathrm{CDCl}_{3}$ ), $\delta 10.06(\mathrm{~m}, 1 \mathrm{H}), 7.96(\mathrm{~m}, 2 \mathrm{H}), 7.73(\mathrm{~m}, 2 \mathrm{H}), 7.54$ (m, 2H), $7.26(\mathrm{~m}, 2 \mathrm{H})$.

4'-chlorobiphenyl-4-ol (23c) [17]. ${ }^{1} \mathrm{H}$ NMR (400 MHz, $\left.\mathrm{CDCl}_{3}\right), \delta 7.45(\mathrm{~m}, 4 \mathrm{H}), 7.37(\mathrm{~m}, 2 \mathrm{H}), 6.90(\mathrm{~m}, 2 \mathrm{H}), 4.88(\mathrm{~m}, 1 \mathrm{H})$.

4-chloro-4'-methylbiphenyl (24c). ${ }^{1} \mathrm{H}$ NMR $(400 \mathrm{MHz}$, $\left.\mathrm{CDCl}_{3}\right), \delta 7.43(\mathrm{~m}, 6 \mathrm{H}), 7.26(\mathrm{~m}, 2 \mathrm{H}), 2.39(\mathrm{~m}, 3 \mathrm{H})$.

4-chloro-4'-ethoxybiphenyl (25c). ${ }^{1} \mathrm{H}$ NMR $(400 \mathrm{MHz}$, $\left.\mathrm{CDCl}_{3}\right), \delta 7.46(\mathrm{~m}, 6 \mathrm{H}), 6.96(\mathrm{~m}, 2 \mathrm{H}), 4.08(\mathrm{~m}, 2 \mathrm{H}), 1.43(\mathrm{~m}, 3 \mathrm{H})$.

4-chloro-4'-nitrobiphenyl (26c). ${ }^{1} \mathrm{H} \mathrm{NMR} \mathrm{(400} \mathrm{MHz}^{\mathrm{CDCl}} 3$ ), 
$\delta 8.11(\mathrm{~m}, 2 \mathrm{H}), 7.70(\mathrm{~m}, 2 \mathrm{H}), 7.26(\mathrm{~m}, 4 \mathrm{H})$.

1-(4'-chlorobiphenyl-4-yl)ethanone (27c) [59]. ${ }^{1} \mathrm{H}$ NMR $\left(400 \mathrm{MHz}, \mathrm{CDCl}_{3}\right), \delta 8.03(\mathrm{~m}, 2 \mathrm{H}), 7.65(\mathrm{~m}, 2 \mathrm{H}), 7.56(\mathrm{~m}, 2 \mathrm{H})$, $7.44(\mathrm{~m}, 2 \mathrm{H}), 2.65(\mathrm{~m}, 3 \mathrm{H})$.

\subsection{General experimental procedure for Suzuki reaction}

In air, aryl halide (0.2 mmol), arylboronic acid ( $0.22 \mathrm{mmol})$, $\mathrm{K}_{2} \mathrm{CO}_{3}(0.3 \mathrm{mmol}), 5 \mathrm{ml}$ of distilled water, and $2 \mathrm{mg}$ of catalyst were combined in a $10 \mathrm{ml}$ round bottom flask. The reaction mixture was magnetically stirred and the temperature was maintained at $75^{\circ} \mathrm{C}$ in an oil bath. Reaction progress was monitored by TLC. After reaction was completed, the reaction mixture was cooled to room temperature and filtrated. The filtrated solid was washed with water (3-5 ml) and dissolved with ethyl acetate. The catalyst was separated by filtration, washed with water, and dried in vacuum. The combined organic phase was dried with anhydrous $\mathrm{MgSO}_{4}$, and the solvent was removed under reduced pressure to give the product.

\subsection{General recycling experimental procedure for Suzuki reaction}

In air, 5 a (0.2 mmol, $37 \mathrm{mg}), \mathbf{1 b}(0.22 \mathrm{mmol}, 26.8 \mathrm{mg})$, $\mathrm{K}_{2} \mathrm{CO}_{3}(0.3 \mathrm{mmol}, 41.4 \mathrm{mg}$ ), $5 \mathrm{ml}$ of distilled water, and $2 \mathrm{mg}$ of catalyst were combined in a $10 \mathrm{ml}$ round bottomed flask. The reaction mixture was magnetically stirred and the temperature was maintained at $75^{\circ} \mathrm{C}$ in an oil bath. Reaction progress was monitored by TLC. After reaction was completed, the reaction mixture was extracted by ethyl acetate four times, then $\mathbf{5 a}(0.2$ mmol, $37 \mathrm{mg}$ ), $\mathbf{1 b}$ (0.22 mmol, $26.8 \mathrm{mg}$ ), $\mathrm{K}_{2} \mathrm{CO}_{3}$ ( $0.3 \mathrm{mmol}, 41.4$ $\mathrm{mg}$ ) were added into the aqueous phase for the next recycling experiment.

\section{Results and discussion}

\subsection{Characterization by TEM and XRD}

The sample was a small drop of the colloidal dispersion deposited onto a piece of copper grid and then dried at room temperature under vacuum. The bio-polymer chains consisted of a range of hydrophobic residues, which made the bio-polymer a moderate to good stabilizer and template for the metal particles. After reduction of $\mathrm{PdCl}_{2}$ by sodium ascorbate in aqueous solution, a dark brown precipitate that was very stable

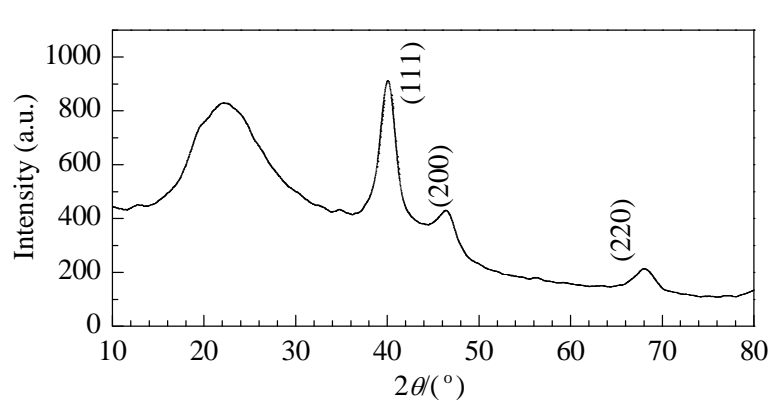

Fig. 2. XRD patterns of the feather keratin-Pd catalyst.

for several months was obtained. The TEM images of the polymer-Pd nanoparticles showed that the particles were quite well dispersed, and the mean diameter of the Pd particles was 3.9 nm (Fig. 1). Three strong diffraction peaks at $2 \theta=39.32^{\circ}$, $45.56^{\circ}$, and $66.82^{\circ}$, corresponding to the diffraction of the (111), (200), and (220) lattice planes of the face centered cubic crystalline structure of the Pd nanoparticles, were clearly seen in the XRD patterns of the feather keratin-Pd catalyst $[20,44]$ (Fig. 2).

\subsection{Suzuki cross-coupling reactions}

Generally, the Suzuki reaction is performed in an organic solvent [45], or in a solvent mixture of water and a polar organic solvent such as $N, N$-dimethylformamide (DMF) [46], NMP ( $N$-methyl-2-pyrrolidone) [44,47], or THF (tetrahydrofuran) [48] or in water with the addition of a surfactant, which helps in the solvation of the organic substrates and the inorganic base [49-52]. However, these strategies usually involve tedious pufication and have low efficiency when a hydrophilic ligand is used or the Pd catalyst is immobilized on a hydrophilic support. The Suzuki reaction can be performed successfully in the solvent of just water [20]. It is known that hydrophobic interactions have a significant influence on organic reactions, and many organic reactions often proceed with much higher rates in water than in organic solvents. The accelerating effect of water has been ascribed to a number of factors, including the hydrophobic effect as well as hydrogen bonding. In our reaction protocols, the Suzuki reaction of 4-bromobenzaldehyde with phenylboronic acid was chosen to optimize the reaction conditions, and we found that the difference between nonhydrophobic and hydrophobic conditions was remarkable. The yields of the corresponding biphenyl products were signifi-

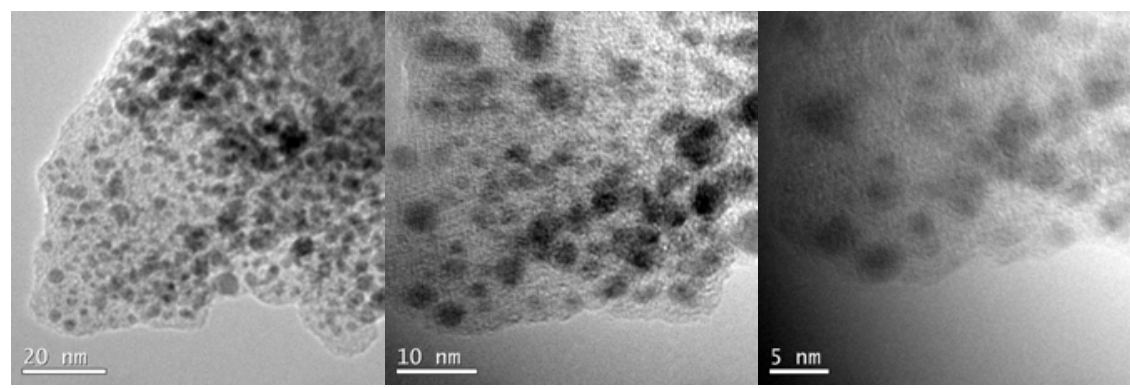

Fig. 1. TEM images of the feather keratin-Pd catalyst.

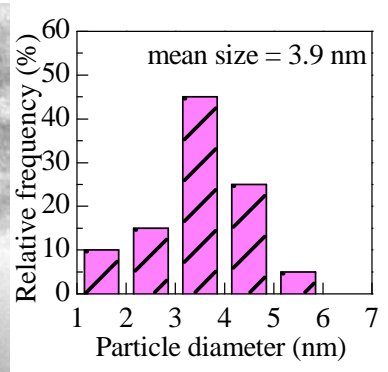


Table 1

Hydrophobic effect in the Suzuki reaction.

\begin{tabular}{cc}
$0.2 \mathrm{mmol}$ \\
\hline$V$ (water): $(\mathrm{THF})$ & Isolated yield (\%) \\
\hline $1: 1$ & 85 \\
$1: 2$ & 63 \\
$1: 3$ & 44 \\
$1: 4$ & 40 \\
$1: 9$ & trace \\
Pure THF & 96 \\
Pure water & \\
\hline
\end{tabular}

cantly lower for the reaction in THF or a mixture of THF/Water than in a pure aqueous phase, despite the aqueous reactions being heterogeneous Table 1. It is probable that in the solvent of water, hydrophobic surfaces benefit from the tendency of water to exclude nonpolar species and thus minimize the Gibbs energy of salvation $[53,54]$.

On the other hand, when the feather keratin-Pd nanoparticles catalyst was used as a nanoreactor for the Suzuki reaction, it was necessary for the reagents to penetrate into the lattice of the polymer and gain access to the Pd catalyst to initiate the reaction. Here, hydrogen bonding possibly played the role that in an aqueous phase, the amino acid chains become stretched by preferential hydrogen bonding with water molecules, which increased the driving force for the hydrophobic guest mole- cules to diffuse into the Pd nanoreactor by an extremely high concentration around the Pd nanoparticle. Therefore the Suzuki reaction in the nanoreactor of Pd-feather is expected to be efficient in water, but in the absence of water, the amino acid chains become contracted because of intermolecular hydrogen bonding between polypeptide chains, which prevent the $\mathrm{Pd}$ nanoreactor from being contacted by reactant molecules. Thus we envisioned that protic solvents used as hydrogen bonding donors have the potential to accelerate the $\mathrm{C}-\mathrm{C}$ formation reaction. More than ten solvents were examined, and obviously, $\mathrm{CH}_{3} \mathrm{OH}, \mathrm{EtOH}$, and $\mathrm{HOCH}_{2} \mathrm{CH}_{2} \mathrm{OH}$ were tested to be beneficial reaction media. However, in the aprotic solvents of toluene and THF, the bio-polymer blocked the passageway access of the reactant molecules to the Pd nanoreactor, and very low yields of coupling product were produced (Fig. 3). We concluded that the large different efficiencies of the halides were not only due to the $\mathrm{C}-\mathrm{X}$ bonding energy, which was in the order of $\mathrm{I}<\mathrm{Br}<\mathrm{Cl}$, but can be also partly ascribed to the support structure and reaction conditions.

It can be seen that the use of the feather protein stabilized $\mathrm{Pd}$ nanoparticles as the catalyst resulted in the dominant formation of the cross-coupling product. The desired products were almost completely precipitated from the aqueous phase after the cooling of the reaction mixture to room temperature. Filtration of the heterogeneous mixture afforded a crude compound with NMR purity. The general reaction condition was optimized as bromobenzene $(0.2 \mathrm{mmol})$, phenyboronic acid

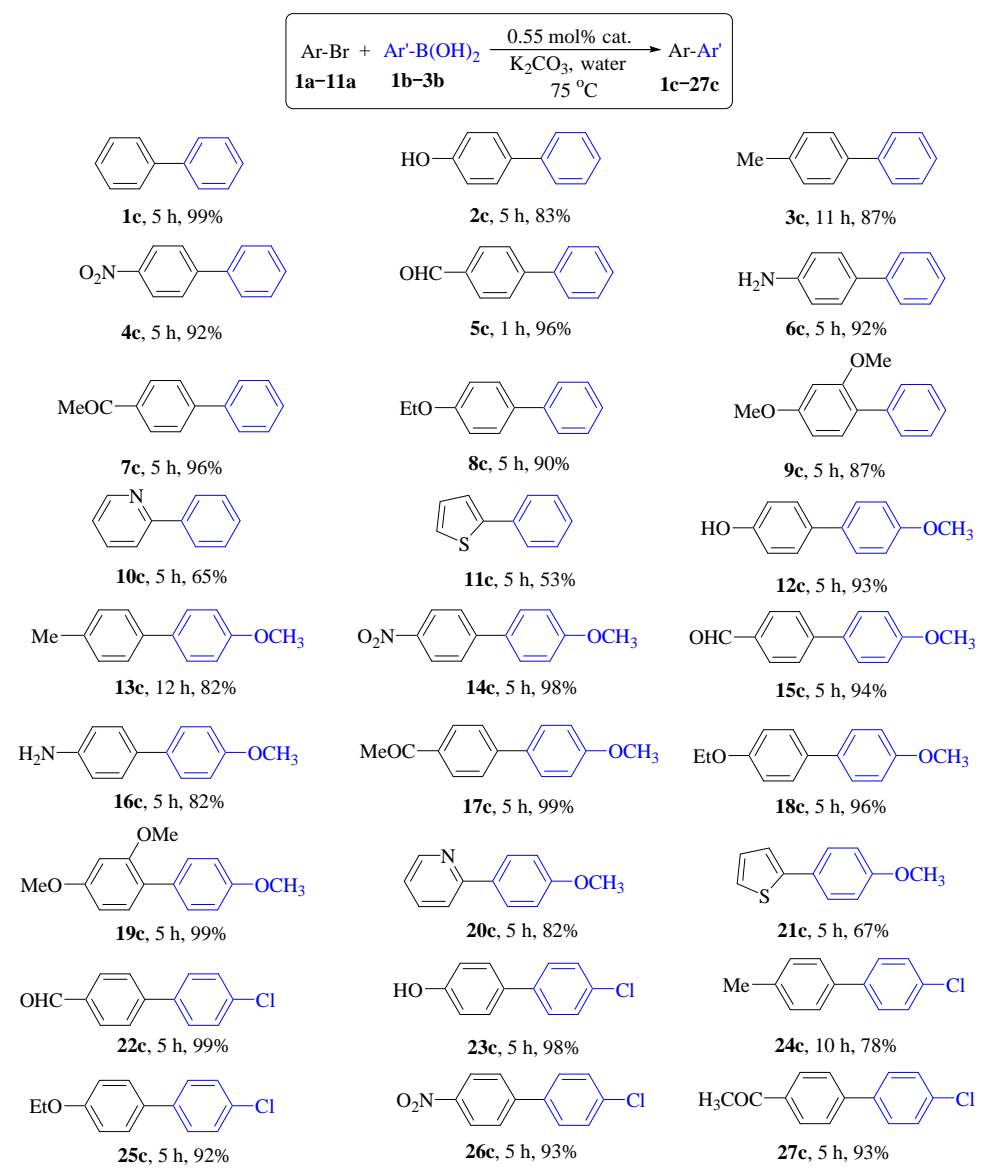

Scheme 1. Scope of the Suzuki reaction with the Pd nano-catalyst. 


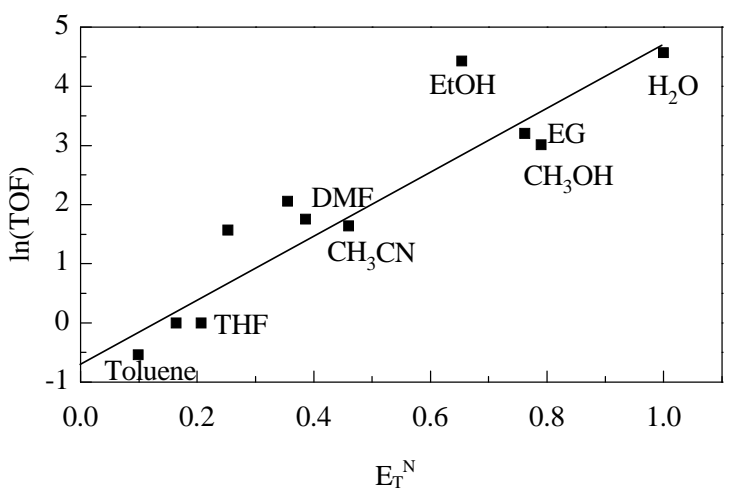

Fig. 3. Effect of the solvent on the Suzuki reaction.

(0.22 mmol), $\mathrm{K}_{2} \mathrm{CO}_{3}(0.3 \mathrm{mmol})$, and $2 \mathrm{mg}$ of Pd catalyst $(0.55$ mol\%) stirred in $5 \mathrm{ml}$ water at $75{ }^{\circ} \mathrm{C}$ under atmosphere conditions.

To explore the scope of the Pd nanoparticles as a catalyst for the Suzuki reactions, the reactions of several typical hydrophilic and hydrophobic aryl halides with benzeneboronic acid were carried out in water at $75^{\circ} \mathrm{C}$. As shown in Scheme 1, the more hydrophilic substrates such as 4-bromophenol, 4-bromobenzaldehyde, 4-bromobenzenamine can be entrapped in the nanoenvironment of the Pd-feather keratin, and all these coupling reactions were quite efficient with yields of biaryls higher than $90 \%$ at $75^{\circ} \mathrm{C}$ in $5 \mathrm{~h}$. As expected, the Suzuki reactions of hydrophobic aryl halides with benzeneboronic acid were relatively unsatisfactory and longer reaction times were required. For instance, the coupling reaction of 1-bromo-4-methylbenzene with benzeneboronic acids only afforded 3c (11 h, 87\% yield), 13c (12 h, 82\%), and 24c (10 h, $78 \%$ ) in moderate yields.

It is documented that the mass transfer rates of the aryl halides and the resultant biaryls between the nanoreactor of Pd catalyst and the solvent of water also play a very important role [55]. When a hydrophilic aryl halide is used, the hydrophilic aryl halide is entrapped in the nanoreactor until the mass dis-

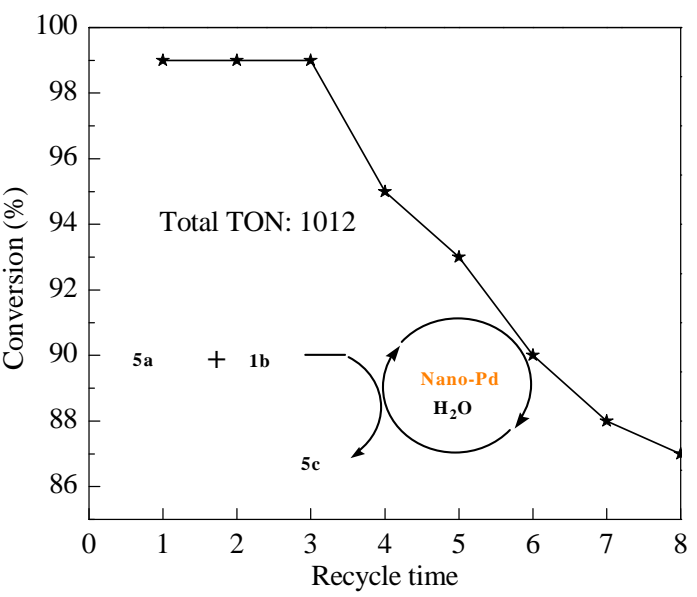

Fig. 4. Recycling test of Pd nanoparticles.

tribution equilibrium between the nanoreactor and the solvent of water is reached. The resulting hydrophilic biaryl can easily diffuse through the nanoreactor into the solvent to reach mass distribution equilibrium, but this is much more difficult for hydrophobic substrates and for the resultant hydrophobic biaryls to diffuse from the nanoreactor into the water. The enriched high concentration of the hydrophobic biaryls in the nanoreactor therefore slows down the Suzuki reaction. To confirm this, competitive Suzuki reactions of a binary mixture of hydrophobic 4-bromoanisole and hydrophilic 4-bromophenol (1:1 by mole number) in the Pd nanoreactor in water was studied. It was found that the competitive reactions afforded 4-hydroxybiphenyl with $>99 \%$ selectivity and $78 \%$ isolated yield at $75{ }^{\circ} \mathrm{C}$ in $2 \mathrm{~h}$. Similar results were also obtained in the arylation of 4-bromobenzaldehyde and 1-bromo4-methylbenzene. Interestingly, the parallel arylation of the more active 4-iodophenol and the less active 4-bromophenol at the same reaction conditions produced $3 \mathbf{c}$ with almost no difference in isolated yields. This result verified that other than the activity of the halides, the mass transfer rates of the reac-
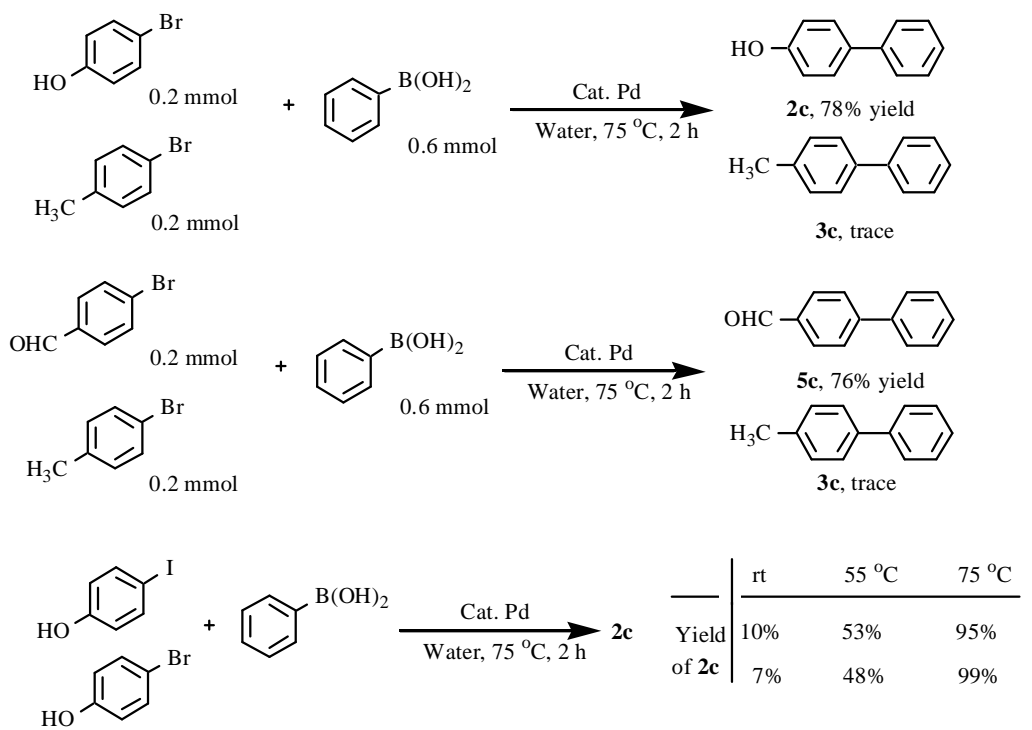

Scheme 2. The competitive Suzuki reactions. 
tants and products between the nanoreactor of Pd-feather keratin and the solvent also has a large influence on the Suzuki reaction (Scheme 2).

In addition, the recyclability of the catalyst was studied in the coupling reaction using the formation of $5 \mathbf{c}$ at $75{ }^{\circ} \mathrm{C}$ with $0.55 \mathrm{~mol} \% \mathrm{Pd}$. Completion of the reaction was accomplished after $5 \mathrm{~h}$ in the first three runs. The activity dropped slightly after the fourth run (Fig. 4). This result probably cannot be explained by leaching during the reaction as the $\mathrm{Pd}$ amount in the reaction mixture after three runs was very low, and was $0.0001 \%$. The activity in the recycling experiments strongly depended on the recycling procedure. The results described above were obtained when extraction was used to separate the water solution of the catalyst from the reaction mixture. Thus, much catalyst loss was inevitable. On the other hand, the ionic strength of the solution was increased upon the addition of the inorganic salt of potassium carbonate, which resulted in the weak adhesion of Pd particles on the feather keratin stabilizer. Therefore, Pd nanoparticles were precipitated out of the solution.

\section{Conclusions}

The immobilization of $\operatorname{Pd}(0)$ on the biopolymer-based material, feather keratin, by chemical coordination and subsequent chemical reduction gave Pd nanoparticles. The Pd nanoparticle catalyst was successfully used in Suzuki-Miyaura coupling reactions. This catalyst is readily available and easy to handle as it is stable in air. Its high activity and very low leaching makes it an attractive alternative to commercial Pd catalysts such as Pd on charcoal.

\section{Acknowledgments}

This work was financially supported by the National Natural Science Foundation of China (21202133), Specialized Research Fund for the Doctoral Program of Higher Education (20050736001) and Young Teacher Research Foundation of Northwest Normal University (NWNU-LKQN-08-8, NWNUkjcxgc-03-73). We also thank Key Laboratory of Eco-Environment-Related Polymer Materials (Northwest Normal University), Ministry of Education, for financial support.

\section{References}

[1] Schmid G. Chem Rev, 1992, 92: 1709

[2] Sun T, Seff K. Chem Rev, 1994, 94: 857

[3] Wen F, Zhang W, Wei G, Wang Y, Zhang J, Zhang M, Shi L. Chem Mater, 2008, 20: 2144

[4] Alonso D A, Najera C. Chem Soc Rev, 2010, 39: 2891

[5] Karbass N, Sans V, Garcia-Verdugo E, Burguete M, Luis S V. Chem Commun, 2006: 3095

[6] Ogasawara S, Kato S. J Am Chem Soc, 2010, 132: 4608

[7] Zheng Z, Li H, Liu T, Cao R. J Catal, 2010, 270: 268

[8] Kochkar H, Aouine M, Ghorbel A, Berhault G. J Phys Chem C, 2011, 115: 11364

[9] Niu W X, Zhang L, Xu G B. ACS Nano, 2010, 4: 1987

[10] Crespo-Quesada M, Andanson J M, Yarulin A, Lim B K, Xia Y N,
Kiwi-Minsker L. Langmuir, 2011, 27: 7909

[11] Karimi B, Akhavan P F. Inorg Chem, 2011, 50: 6063

[12] Wen F, Zhang W, Wei G, Wang Y, Zhang J, Zhang M, Shi L. Chem Mater, 2008, 20: 2144

[13] Yin M Y, Yuan G L, Wu Y Q, Huang M Y, Jiang Y Y. J Mol Catal A, 1999, 147: 93

[14] Zhou D Q, He M, Zhang Y H, Huang M Y, Jiang Y Y. Polym Adv Technol, 2003, 14: 287

[15] Xu Y, Zhang L, Cui Y.J Appl Polym Science, 2008, 110: 2996

[16] Molnár Á. Chem Rev, 2011, 111: 2251

[17] Gallon B J, Kojima R W, Kaner R B, Diaconescu P L. Angew Chem, Int $E d, 2007,46: 7251$

[18] Cho J K, Najman R, Dean T W, Ichihara O, Muller C, Bradley M. J Am Chem Soc, 2006, 128: 6276

[19] Schweizer S, Becht J M, Le Drian C. Tetrahedron, 2010, 66: 765

[20] Nishio R, Sugiura M, Kobayashi S. Chem Asian J, 2007, 2: 983

[21] Zhang M, Zhang W.J Phys Chem C, 2008, 112: 6245

[22] Ohtaka A, Teratani T, Fujii R, Ikeshita K, Shimomura O, Nomura R. Chem Commun, 2009: 7188

[23] Kitade Y, Sako S, Tsutsui A, Monguchi Y, Maegawa T, Sajiki H. Adv Synth Catal, 2010, 352: 718

[24] Wen F, Zhang W, Wei G, Wang Y, Zhang J, Zhang M, Shi L. Chem Mater, 2008, 20: 2144

[25] Miyaura N, Suzuki A. Chem Rev, 1995, 95: 2457

[26] Suzuki A. J Organomet Chem, 1999, 576: 147

[27] Kotha S, Lahiri K, Kashinath D. Tetrahedron, 2002, 58: 9633

[28] Franzen R, Xu Y. Can J Chem, 2005, 83: 266

[29] Miyaura N. Top Curr Chem, 2002, 219: 11

[30] Zhu M Y, Diao G W. J Phys Chem C, 2012, 116: 1626

[31] Pérez-Lorenzo Moisés. J Phys Chem Lett, 2012, 3: 167

[32] Hariprasad E, Radhakrishnan T P. ACS Catal, 2012, 2: 1179

[33] Kim M J, Park J C, Kim A, Park K H, Song H. Langmuir, 2012, 28 : 6441

[34] Chtchigrovsky M, Lin Y, Ouchaou K, Chaumontet M, Robitzer M, Quignard F, Taran F. Chem Mater, 2012, 24: 1505

[35] Wu S, Ma H C, Jia X J, Zhong Y M, Lei Z Q. Tetrahedron, 2011, 67: 250

[36] Spiridon I, Paduraru O M, Rudowski M, Kozlowski M, Darie R N. Ind Eng Chem Res, 2012, 51: 7279

[37] Yin J, Rastogi S, Terry A E, Popescu C. Biomacromolecules, 2007, 8: 800

[38] Hu C Y, Reddy N, Yan K, Yang Y Q. J Agric Food Chem, 2011, 59: 10517

[39] Ullah A, Vasanthan T, Bressler D, Elias A L, Wu J P. Biomacromolecules, 2011, 12: 3826

[40] Jin E Q, Reddy N, Zhu Z F, Yang Y Q. J Agric Food Chem, 2011, 59: 1729

[41] Poole A J, Church J S, Huson M G. Biomacromolecules, 2009, 10: 1

[42] Li F Y, Wang R M, He Y F, Li X X, Song P F, Ying X C, Mao C W. J Control Release, 2011, 152: 92

[43] Wang R M, Li F Y, Wang X J, Li Q F, He Y F, Wang Y B. Funct Mater Lett, 2010, 3: 213

[44] Park J C, Heo E J, Kim A, Kim M J, Park K H, Song H J.J Phys Chem C, 2011, 115: 15772

[45] Bedford R B, Singh V G, Walton R I, Williams R T, Davis S A. Chem Mater, 2005, 17: 701

[46] Zhang P, Weng Z H, Guo J, Wang C C. Chem Mater, 2011, 23: 5243

[47] Niembro S, Vallribera A, Moreno-Mañas M. New J Chem, 2008, 32 : 94

[48] Lu F, Ruiz J, Astruc D. Tetrahedron Lett, 2004, 45: 9443

[49] Barder T E, Walker S D, Martinelli J R, Buchwald S L. J Am Chem Soc, 2005, 127: 4685 


\section{Graphical Abstract}

Chin. J. Catal., 2013, 34: 578-584 doi: 10.1016/S1872-2067(11)60472-5

Nanoparticle palladium catalyst stabilized by supported on feather keratin for Suzuki coupling reaction

MA Hengchang*, BAO Zhikang, HAN Guobing, YANG Ningning, XU Yufei, YANG Zengming, CAO Wei, MA Yuan

Northwest Normal University

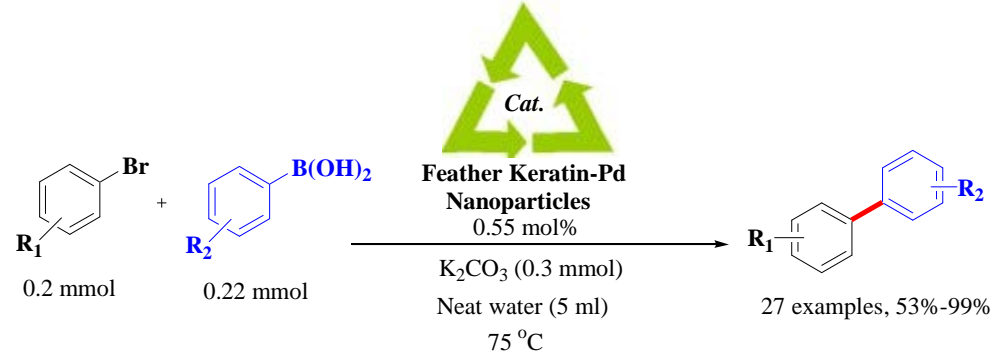

Feather keratin entrapped palladium nanoparticles efficiently catalyzed Suzuki coupling reactions in aqueous medium under mild reaction conditions, and the catalyst can be reused.

[50] Doucet H. Eur JOrg Chem, 2008: 2013

[51] Kinzel T, Zhang Y, Buchwald S. L.J Am Chem Soc, 2010, 132: 14073

[52] Solodenko W, Schön U, Messinger J, Glinschert A, Kirschning A. Synlett, 2004, 10: 1699

[53] Soomro S S, Rohlich C, Kohlerb K. Adv Synth Catal, 2011, 353: 767

[54] Ruan J W, Xiao J L. Acc Chem Res, 2011, 44: 614

[55] Wei G, Zhang W, Wen F, Wang Y, Zhang M. J Phys Chem C, 2008 ,
112,10827

[56] Chen W, Li P, Wang L. Tetrahedron, 2011, 67: 318

[57] Mohanty S, Suresh D, Balakrishna M S, Mague J T. Tetrahedron, 2008, 64: 240

[58] Leadbeater N E, Marco M. Org Lett, 2002, 4: 2973

[59] Kim J H, Kim J W, Shokouhimehr M, Lee Y. J Org Chem, 2005, 70: 6714

\section{羽毛角蛋白稳定的钯纳米颗粒催化 Suzuki 偶联反应 \\ 马恒昌*, 包志康, 韩国斌，杨宁宁，许玉菲，杨增明，曹伟，马源 西北师范大学化学化工学院, 甘肃省高分子化学与物理重点研究室, \\ 教育部生态环境相关高分子重点实验室, 甘肃兰州 730070}

摘要: 采在温和条件下羽毛角蛋白负载的 Pd 纳米颗粒可高效催化水中溴代芳烃与苯硼酸的偶联反应, 且具有官能团的广泛适用 性,生成的联苯类化合物可在反应液中沉淀出来, 具有很好的产率和纯度. 催化剂通过简单过滤可重复使用 7 次.

关键词: Suzuki 偶联反应; 纳米颗粒; 羽毛角蛋白; 疏水效应; 水相

收稿日期: 2012-09-30. 接受日期: 2012-10-23. 出版日期: 2013-03-20.

*通讯联系人. 电话/传真: (0931)7975257; 电子信箱: mahczju@hotmail.com

基金来源：国家自然科学基金(21202133).

本文的英文电子版由Elsevier出版社在ScienceDirect上出版(http://www.sciencedirect.com/science/journal/18722067). 